\title{
Establishing Sapogenin-Bearing Dioscoreas from Seed
}

\section{Herminio Delpin and Franklin W. Martin ${ }^{1}$}

\section{INTRODUCTION}

The sapogenin-bearing Dioscorea species, sources of precursors of steroidal drugs, may be propagated from seeds, stem cuttings or tuber pieces. The success of propagation from stem cuttings varies with season of the year, age of the propagating material, clone, and technique (3). ${ }^{2}$ Propagation by tuber pieces, on the other hand, reduces the net amount of tubers available from the crop (4), and success is strongly influenced by seasonal dormancy, selection of cutting materials, tuber diseases, and techniques (2). Observations and experiments conducted over the years show that propagation from seed is rapid, economical, and fairly free of complications. Seedling transplants, however, are difficult to establish in the field because they are small and rather weak during the first growing season. They also vary in growth rate, vigor, and sapogenin content.

The experiments reported below were made to evaluate the effects of season on seeding, age of transplanting, and technique of planting on survival and growth of Dioscorea seedlings.

\section{MATERIALS AND METHODS}

Seeds for the experimental plantings were stored under cool, dry conditions for 3 to 12 months before planting. Selected varieties of two Dioscorea species were used: D. composita Hemsl (P. I. 201783) from Mexico, and D. floribunda Mart. and Gal. (F. E. S. 11566) from Costa Rica.

Planting beds, consisting of wooden frames and plastic overhead shelters, were filled with 6 inches of a mixture of $3 / 4$ Toa loam soil and $1 / 4$ cachaza (sugarcane filter press cake). The soil was pulverized and fumigated with methyl bromide gas 1 week before planting. Seeds were planted $1 / 4$ inch deep, spaced 11/4 inches apart, and covered with a mixture of 1/2 sand and 1/2 shredded peat moss. Such plantings were established once each 3 months for 1 year. The beds were kept moist, sprayed for fungus control as necessary, and fertilized regularly. Percentage of seeds germinated was estimated from samples of 100 plants 4 weeks after planting seed. When vines appeared, small bamboo stakes were placed in the beds at the rate of 4 stakes per square foot. The vines soon climbed these stakes. Growth rates of

1 Agricultural Research Technician and Plant Geneticist, Federal Experiment Station, Crops Research Division, Agricultural Research Service, USDA, Mayagũez, Puerto Rico.

Italic numbers in parentheses refer to Literature Cited, p. 340. 
vines and tubers were checked 4 weeks after seeding, and each 2 weeks thereafter until the plants were transplanted in the field.

At intervals of 3, 4, and 5 months after planting the beds, 200 seedlings of each species were removed for planting in the field. Two techniques were used. In one case, the tubers were planted upright 1 to 2 inches deep in the soil. A 6- to 8-inch remnant of the stem was used to orient the tuber. In another plot, stems were completely removed and tubers were planted at the same depth but without attempting to orient them upright. All were spaced 8 inches apart in 40-inch rows and staked with individual bamboo poles. The treatments were replicated 4 times in a completely randomized design. The soil was Cialitos clay. The plots were irrigated as necessary, maintained free of weeds, and fertilized at the rate of 1,000 pounds per acre (10-10-8). Survival and dormancy were measured each

TABLE 1.-Approximate percentage germination of Dioscorea seed in four beds planted at four dates

\begin{tabular}{c|c|c}
\hline \multirow{2}{*}{ Planting date } & \multicolumn{2}{|c}{ Species } \\
\cline { 2 - 3 } & D. composila & D. floribunda \\
\hline & Percent & Percent \\
June 23, 1966 & 80 & 70 \\
September 9, 1966 & 71 & 80 \\
December 5, 1966 & 60 & 70 \\
March 3, 1967 & 65 & 60 \\
\hline
\end{tabular}

month, as the number of living vines per replicate. At the termination of the experiment 1 year after the final planting, all plots were dug, and the surviving tubers were counted and weighed.

\section{RESULTS}

\section{ESTABLISHMENT OF BEDDLINGS}

The percentage of germination of seeds was satisfactory in all tests, and was not affected by either the season of planting or species (table 1). No seasonal dormancy occurred in the planting beds, and vegetative and vine growth appeared normal at all seasons. This growth pattern contrasts with that of field grown plantings. $D$. floribunda normally dies back during the dry season and remains in a dormant condition until the spring rains begin.

The tubers grew very slowly during the first 5 weeks after germination (8 weeks after planting seeds). Thereafter the rate of growth increased 


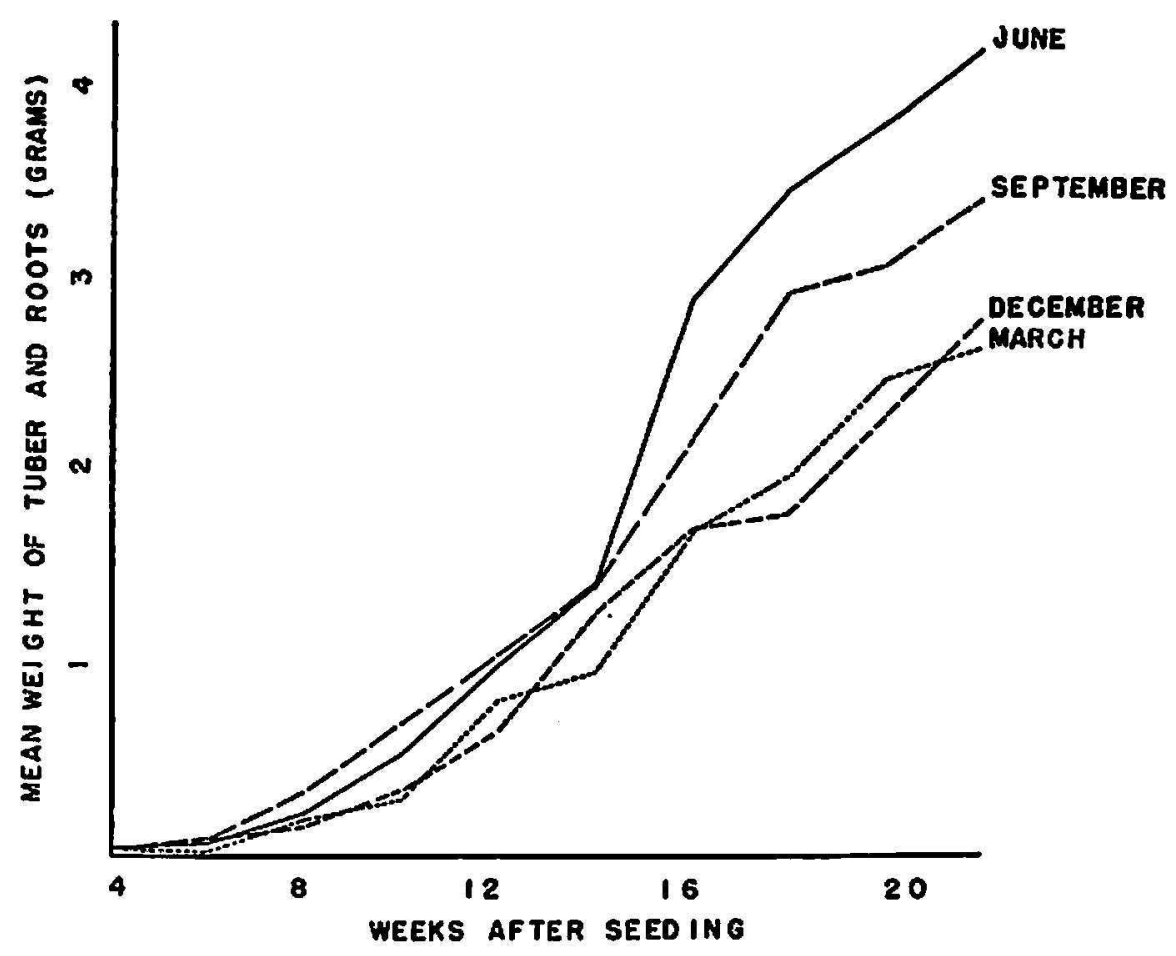

Fia. 1.-Mean rate of growth of Dioscorea composita seedlings.

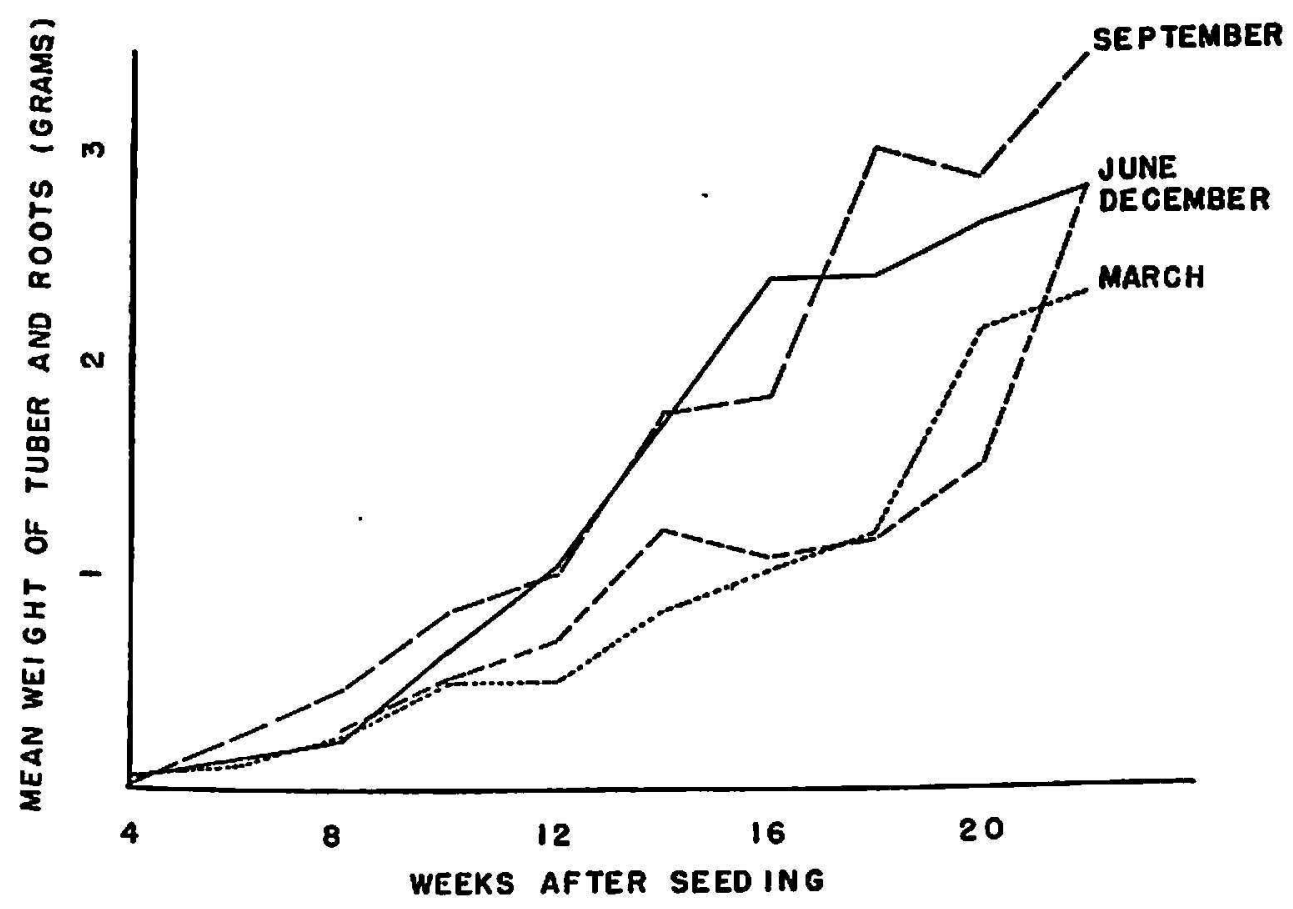

FIG. 2.-Mean rate of growth of Dioscorea floribunda seedlings.

and was more or less uniform during the period from 8 to 22 weeks after planting (figs. 1 and 2). The fact that curves continued upward at 22 weeks suggests that the plants had not yet been stunted by crowding in the seedbed. Seedlings from June and September plantings apparently 
grew more rapidly than those from December and March. These differences, however, were not tested statistically.

\section{SURVIVAL OF SEEDLINGS}

Dioscorea floribunda seedlings survived better than those of $D$. composita (table 2). In both species about one-third of the seedlings alive 4 months

TABLE 2.-Survival of Dioscorea seedlings influenced by species, time of planting, age of planting, and planting treatment ${ }^{1}$

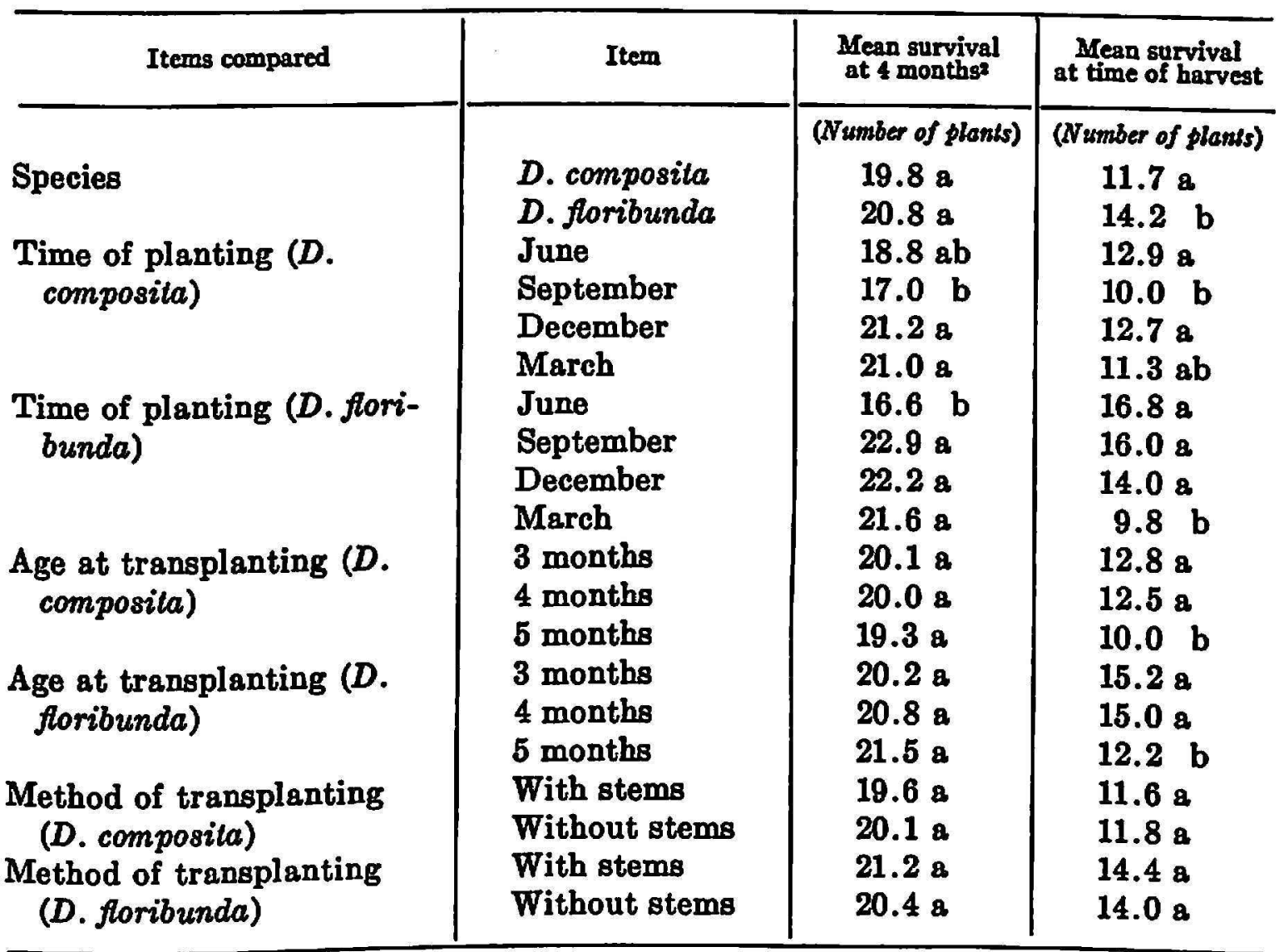

${ }^{1}$ In this and subsequent tables, means of a set followed by the same letter are not significantly different $(p=0.05)$.

2 Based on 25 plants per replication.

after transplanting failed to survive until harvest. Survival of seedlings was affected by season of planting, but the differences in survival were small and were not consistent for the two species. Survival 4 months after planting was not related to survival until harvest. Planting schedules that led to transplanting during the dry winter months (December to March) appeared to result in as satisfactory survival as other schedules. Seedlings transplanted 3 or 4 months after seeding survived as well or better than those transplanted 5 months after seeding. The method of 
transplanting, with or without stem and orientation in the soil, did not affect survival.

\section{WEIGHT OF TUBER}

Because the 4 seedling beds had been planted at different times, the final weight of the tubers was influenced chiefly by this variable (table 3). June and September plantings yielded alike, but December plantings were considerably less productive than those of September. The age at which the seedling plants were transplanted to the field did not affect the final weight of tuber or total yield in the case of $D$. composita. However,

TABLE 3.-Weight of Dioscorea tubers as influenced by species, time of planting, age of planting, and planting trealment

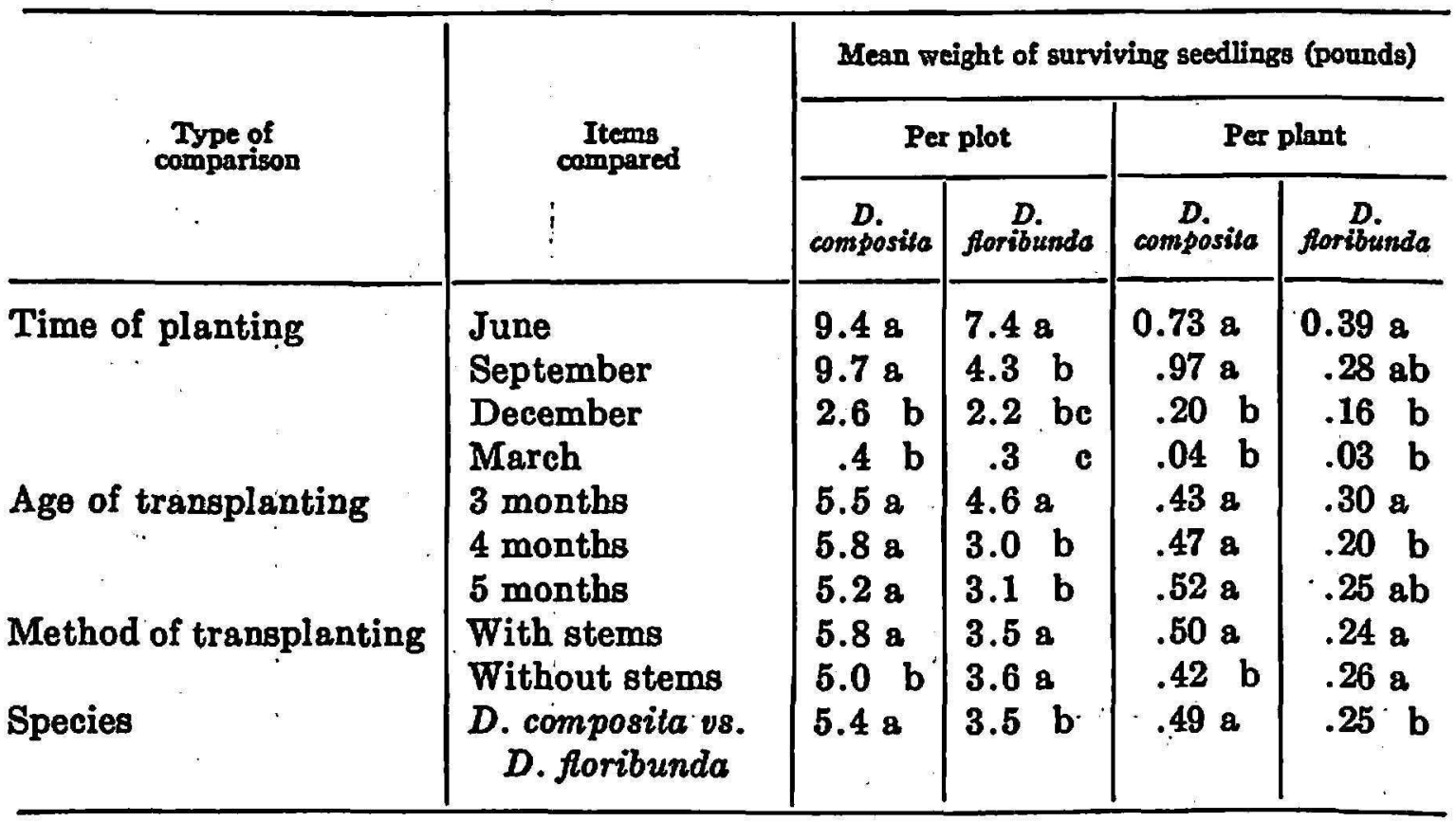

seedlings of $D$. floribunda planted at 3 months of age outyielded seedlings planted at either 4 or 5 months of age. Although planting seedling tubers without stem or orientation in the soil decreased yields of $D$. composita about 18 percent, this practice did not affect yields of $D$. floribunda. The two species differed also in mean weight per plot or per tuber. The large size of $D$. composita tubers more than compensated in final weight for the lower rate of survival of this species.

When the data from the individual planting dates are compared (table 4) significant differences are seen in tuber weight due to age of transplanting. However, these differences are not consistent within or between species and probably are not attributed to age of transplanting per se. We suspect that unmeasured factors such as condition of the soil at transplanting, and subsequent moisture stress, may have caused the erratic results. Never- 
theless, the data suggest that differences in yield due to age of transplant are small. If this is so, date of transplant need not be rigidly controlled during the planting season, and other factors such as weather and soil condition can be used to determine the time of transplanting.

\section{DISCUSSION AND CONCLUSIONS}

The variables investigated in these studies proved to be of minor importance within the frame work of the agronomic system used. Unmeasured variables such as weather and condition of the soil could have accounted for most of the variation observed in survival and final tuber weights. When planting beds are properly prepared and maintained, and when

TABLE 4.-Effecl of age of transplant on tuber weight (in pounds per original 25 plants)

\begin{tabular}{c|c|c|c|c}
\hline \multirow{2}{*}{$\begin{array}{c}\text { Age at } \\
\text { transplanting }\end{array}$} & \multicolumn{4}{|c}{ Time of transplanting } \\
\cline { 2 - 4 } & June & September & December & March \\
\hline & \multicolumn{5}{|c}{ D. composila } \\
\hline 3 months & $9.2 \mathrm{a}$ & $5.8 \mathrm{a}$ & $2.8 \mathrm{a}$ & $.51 \mathrm{a}$ \\
4 months & $5.7 \mathrm{~b}$ & $4.2 \mathrm{a}$ & $1.9 \mathrm{a}$ & $.26 \mathrm{~b}$ \\
5 months & $7.4 \mathrm{ab}$ & $2.9 \mathrm{~b}$ & $1.7 \mathrm{a}$ & $.28 \mathrm{~b}$ \\
\hline & \multicolumn{5}{|c|}{ D. floribunda } \\
\hline & $8.4 \mathrm{~b}$ & $8.8 \mathrm{a}$ & $4.0 \mathrm{a}$ & $.16 \mathrm{~b}$ \\
& $11.0 \mathrm{a}$ & $10.6 \mathrm{a}$ & $1.3 \mathrm{~b}$ & $.24 \mathrm{ab}$ \\
& $8.1 \mathrm{~b}$ & $2.5 \mathrm{ab}$ & $.35 \mathrm{a}$ \\
\hline
\end{tabular}

plantings are irrigated as necessary, then the season of sowing, age of seedling when transplanted, and method of transplanting apparently do not seriously affect either survival or yield of the two species tested. These conditions should be verified at time of harvest of mature plantings. The species themselves differed, according to previously described patterns (1). These results suggest that the farmer may adopt a very flexible program in the production of seedlings and their subsequent transplanting to the field, if irrigation is provided during dry periods.

The sapogenin-bearing yams require an inordinate amount of hand labor. To make the crop a commercial success, many operations must be mechanized. With respect to transplanting, the current studies suggest that the seedling tubers themselves can be seeded mechanically without orientation. Survival appears to be the same in the case of both species, but yields of $D$. composita may be slightly reduced by the practice. 


\section{SUMMARY}

The influence of three factors in the survival of seedlings of two sapogeninbearing Dioscorea species were tested: Season of the year to establish the seedbed, age of the plant at transplanting, and the orientation of the tuber in the soil (with orientation and stem, or without orientation and no stem). No strong or consistent differences between treatments could be demonstrated. This indicates that the farmer can develop his plantings under a flexible system, if dry-season irrigation is practiced. The planting can be adapted for mechanization by seeding tubers directly into the soil without stem and with random orientation.

\section{RESUMEN}

Se investigó la influencia de tres factores en cuanto a la supervivencia de plantas obtenidas de semillas de dos especies de Dioscorea, a saber, la estación del año para establecer el vivero, edad de la planta al trasplantarla y método de siembra del tubérculo (con orientación y tallo, o con tallo removido y sin orientación). No hubo diferencias grandes o consistentes entre los tratamientos bajo condiciones de riego durante la temporada de sequía. Esto indica que el agricultor puede cuidar de sus viveros y hacer sus siembras bajo un sistema muy flexible. La siembra puede adaptarse a la mecanización si se siembran los tubérculos directamente en el suelo sin tallo y sin orientación.

\section{LITERATURE CITED}

1. Cruzado, H. J., Delpín, H., and Roark, B. A., Sapogenin production in relation to age of tuber in two Dioscorea species, Turrialba 15 (1): 25-8, 1965.

2. Gregory, L. E., Factors that influence vegetative bud development in rootstock segments of Dioscorea composita and D. floribunda, J. Agr. Univ. P.R. 52 (2): 155-63, 1968.

3. Martin, F. W., and Delpín, H., Techniques and problems in the propagation of sapogenin-bearing yams from stem cuttings, J. Agr. Univ. P.R. 68 (3): 191-98, 1969.

4. Martin, F. W., and Gaskins, M. H., Cultivation of the sapogenin-bearing Dioscorea species, Prod. Res. Rep. No. 103, ARS, USDA, 19 pp., 1968. 